CIVICS EDUCATION AND SOCIAL SCIENSE JOURNAL(CESSJ)

Volume 2 Nomor 2 Edisi Bulan Desember 2020

\title{
PROBLEMATIKA PEMBELAJARAN SEJARAH DARING DAN SOLUSINYA DI MASA PANDEMI COVID 19 DALAM PERSPEKTIF PENDIDIKAN KARAKTER BAGI SISWA KELAS X DI SMA VETERAN 1 SUKOHARJO TAHUN PEMBELAJARAN 2020-2021
}

\author{
Penulis \\ Yuliani SW \\ Dosen Program Studi PGSD \\ Fakultas Keguruan Dan Ilmu Pendidikan \\ Universitas Veteran Bangun Nusantara Sukoharjo \\ Email: yuliani@gmail.com
}

\begin{abstract}
ABSTRAK
Tujuan penelitian ini adalah untuk mendeskripsikan problematika pembelajaran daring dan solusinya dalam masa pandemic covid 19 dalam perspektif pendidikan karakter bagi siswa kelas X di SMA Veteran 1 Sukoharjo Tahun Pembelajaran 2020-2021. Jenis penelitiannya adalah penelitian deskriptif kualitatif, dengan subjek penelitiannya: guru bidang Studi sejarah dan siswa kelas $\mathrm{X}$ di SMA Veteran 1 Sukoharjo Tahun Pembelajaran 2020-2021, objek penelitiannya adalah pembelajaran sejarah daring, dan pendidikan karakter. Metode pengumpulan data menggunakan: wawancara dengan aplikasi google form, WA dan dokumntasi.

Validitas data dilakukan dengan trianggulasi sumber dan metode. Hasil penelitian: berdasarkan informasi yang diperoleh dari guru bidang studi sejarah maupun dari siswa kelas X di SMA Veteran 1 Sukoharjo diperoleh informasi; berbagai problema yang dihadapi guru Bidang Studi Sejarah dan siswa dalam pembelajaran sejarah daring di masa pandemic covid 19 adalah sebagai berikut: koneksi internet yang tidak stabil, kurangnya penguasaan aplikasi yang digunakan dan sering error, dukungan HP yang tidak kurang mendukung aplikasi, pengembangan bahan ajar kurang maksimal, penerapan metode dan media kurang variatif, kurang dapat mnjangkau nilai-nilai karakter secara maksimal, pengumpulan tugas tidak tepat waktu, merepotkan orang tua dalam mendampingi belajar pitra putrinya karena orang tua kurang memahami IT. Simpulannya bahwa problematika pembelajaran sejarah daring dalam perspektif pendidikan karakter sangat kompleks, dan harus dicarikan solusinya.
\end{abstract}

Kata-Kata Kunci: pembelajaran sejarah, daring dan pendidikan karakter 
CIVICS EDUCATION AND SOCIAL SCIENSE JOURNAL(CESSJ)

Volume 2 Nomor 2 Edisi Bulan Desember 2020

\title{
PROBLEMATICS OF LEARNING HISTORY OF LINE AND ITS SOLUTIONS IN THE TIME (ANDEMI COVID 19 IN THE PERSPECTIVE OF CHARACTER EDUCATION FOR CLASS X STUDENTS AT VETERAN 1 HIGH SCHOOL, SUKOHARJO IN THE STUDY YEAR 2020-2021
}

\author{
Author \\ Yuliani SW \\ PGSD Study Program Lecturer \\ Faculty of Teacher Training and Education \\ Bangun Nusantara Sukoharjo Veteran University \\ Email: yuliani@gmail.com
}

\begin{abstract}
The purpose of this study was to describe the problems of online learning and their solutions during the Covid 19 pandemic in the perspective of character education for grade X students at SMA Veteran 1 Sukoharjo for the 2020-2021 academic year. This type of research is a qualitative descriptive study, with the research subjects: teachers in the field of historical studies and class $\mathrm{X}$ students at SMA Veteran 1 Sukoharjo Academic Year 2020-2021, the research objects are online history learning and character education. Data collection methods used: interviews with the google form application, WA and documentation.

The data validity was done by triangulating sources and methods. Research results: based on information obtained from teachers in the field of history studies and from class $\mathrm{X}$ students at SMA Veteran 1 Sukoharjo, information was obtained; the various problems faced by teachers in the field of history and students in learning history online during the Covid 19 pandemic are as follows: unstable internet connection, lack of mastery of applications used and frequent errors, HP support that does not support applications less maximally, the application of methods and media is less varied, less able to reach maximum character values, submission of assignments is not on time, inconvenient for parents in accompanying their daughter's learning because parents do not understand IT. The conclusion is that the problems of learning history online in the perspective of character education are very complex, and a solution must be found.
\end{abstract}

Keywords: history learning, online and character education 


\section{PENDAHULUAN}

Pembelajaran adalah suatu proses yang terencana, terprogram, kontinu dan berkelanjutan. (Hernawan, 2018). Dalam pembelajaran guru harus memberdayakan semua komponen pembelajaran secara maksimal agar tujuan pembelajaran dapat tercapai secara optimal.komponen-komponen pembelajaran mencakup: guru, siswa, kurikulum, tujuan, bahan ajar, metode, media, lingkungan pembelajaran, sarana dan prasarana pembelajaran serta evaluasi pembelajaran.(Ahmad Johari, 2008). Pada situasi saat ini pembelajaran dilakukan secara daring artinya dilakukan melalui media social dengan aplikasi tertentu sehingga tidak ada interaksi langsung antara guru dengan peserta didik.(Baxter et al., 2008). Pembelajaran secara daring dimaksudkan untuk memutus mata rantai penularan virus covid 19 yang saat ini melanda di Negara-negara sedunia. (Dewi, 2020).

Dalam konteks pembelajaran bidang studi sejarah secara daring saat ini memang merupakan sesuatu hal baru sehingga diperlukan suatu mind seat, strategi yang baru pula(Jamaluddin et al., 2020). Kunci utama kelancaran dalam pembelajaran daring adalah penguasaan IT serta dukungan sarana prasarana HP.

Pembelajaran sejarah daring dalam perspektif pendidikan karakter di kelas X di SMA Veteran 1 Sukoharjo Pada tahun Pembelajaran 2020-2021 ditemukan permasalahan yang sangat komplek baik dihadapi guru bidang studi sejarah, siswa kelas X maupun orang tua siswa. Meski demikian harus dicarikan solusinya agar pembelajaran sejarah tetap berjalan dan meminimalisir problematika yang dihadapi.

Pada penelitian ini difokuskan pada problematika pembelajaran sejarah daring dan solusinya dalam perspektif pendidikan karakter bagi siswa kelas $\mathrm{X}$ di SMA Veteran 1 Sukoharjo tahun Pembelajaran 2020-2021. Pokok permasalahan dalam penelitian ini dirumuskan bagaimanakah problematika pembelajaran sejarah daring dan solusinya dalam perspektif pendidikan karakter bagi siswa kelas X di SMA Veteran 1 Sukoharjo tahun Pembelajaran 2020-2021? Dan tujuan penelitiannya untuk mendeskripsikan problematika pembelajaran sejarah daring dan solusinya dalam perspektif pendidikan karakter bagi siswa kelas X di SMA Veteran 1 Sukoharjo tahun Pembelajaran 2020-2021.

\section{KAJIAN TEORI}

Sejarah digambarkan sebagai masa lalu manusia dan seputarnya yang disusun secara ilmiah dan lengkap meliputi urutan fakta masa tersebut dengan tafsiran dan penjelasan yang memberi pengertian dan kefahaman tentang apa yang berlaku. Sejarah adalah cabang ilmu yang mengkaji secara sistematis keseluruhan perkembangan proses perubahan dan dinamika kehidupan masyarakat dengan segala aspek kehidupannya yang terjadi di masa lampau (Sardiman, 2003: 9). Sedangkan menurut Ibn Khaldun dalam Abdurahman (2007: 5), mengemukakan bahwa sejarah merupakan hasil upaya penemuan kebenaran, eksplanasi kritis tentang sebab dan genesis kebenaransesuatu serta kedalaman pengetahuan tentang 
bagaimana dan mengapa peristiwa-peristiwa terjadi.Berdasarkan definisi di atas, maka dapat disimpulkan bahwa pembelajaran sejarah adalah proses interaksi antara siswa dengan lingkungannya, sehingga terjadi perubahan tingkah laku akibat dari interaksinya dengan mempelajari sejarah. Pembelajaran sejarah tidak hanya menghafal dan mengenang peristiwa-peristiwa sejarah yang telah lalu saja. Tetapi pembelajaran sejarah mempunyai tujuan agar siswa mampu mengembangkan kompetensi untuk berpikir secara kronologi dan memiliki pengetahuan masa lampau untuk dapat memahami dan menjelaskan proses perkembangan dan perubahan masyarakat dengan keanekaragaman sosial budaya dalam rangka menemukan jati diri bangsa, serta bisa menumbuhkan jati dirinya sebagai suatu bagian dari suatu bangsa Indonesia.

Secara sederhana, Pembelajaran sejarah diartikan sebagai suatu sistem belajar mengajar sejarah. Pembelajaran sejarah berkaitan dengan teori-teori kesejarahan. (Sirnayatin, 2017) Berbeda dengan ilmu sejarah, pembelajaran sejarah atau mata Pembelajaran sejarah dalam kurikulum sekolah memang tidak secara khusus bertujuan untuk memajukan ilmu atau untuk menelorkan calon ahli sejarah, karena penekanannya dalam Pembelajaran sejarah tetap terkait dengan tujuan pendidikan pada umumnya yaitu ikut membangun kepribadian dan sikap mental siswa. Sutrisno Kuntoyo (1985 :46) menyatakan bahwa kesadaran sejarah paling efektif diajarkan melalui pendidikan formal. Hamid Hasan berpendapat, terdapat beberapa pemaknaan terhadap pendidikan sejarah. Pertama, secara tradisional pendidikan sejarah dimaknai sebagai upaya untuk mentransfer kemegahan bangsa di masa lampau kepada generasi muda. Dengan posisi yang demikian maka pendidikan sejarah adalah wahana bagi pewarisan nilai-nilai keunggulan bangsa. Melalui posisi ini pendidikan sejarah ditujukan untuk membangun kebanggaan bangsa dan pelestarian keunggulan tersebut. Kedua, pendidikan sejarah berkenaan dengan upaya memperkenalkan peserta didik terhadap disiplin ilmu sejarah. Oleh karena itu kualitas seperti berpikir kronologis, pemahaman sejarah, kemampuan analisis dan penafsiran sejarah, kemampuan penelitian sejarah, kemampuan analisis isu dan pengambilan keputusan (historical issues-analysis and decision making) menjadi tujuan penting dalam pendidikan sejarah (Hasan Hamid, 2007: 7).

I Gde Widja (1989: 23) menyatakan bahwa pembelajaran sejarah adalah perpaduan antara aktivitas belajar dan mengajar yang di dalamnya mempelajari tentang peristiwa masa lampau yang erat kaitannya dengan masa kini. Pendapat I Gde Widya tersebut dapat disimpulkan jika mata Pembelajaran sejarah merupakan bidang studi yang terkait dengan fakta-fakta dalam ilmu sejarah namun tetap memperhatikan tujuan pendidikan pada umumnya.

Dalam Seminar Sejarah Nasional di Yogyakarta tahun 1957, Padmopuspito berpendapat bahwa pertama, penyusunan Pembelajaran sejarah harus bersifat ilmiah. Kedua, siswa perlu bimbangan dalam berfikir tetapi tafsiran dan penilaian tidak boleh dipaksakan, karena dapat mematikan daya pikir siswa (Sidi Gasalba, 1966:169). Dalam bidang Pembelajaran sejarah, terdapat tiga faktor yang harus dipahami tentang materi sejarah. Pertama, hakekat fakta sejarah. Kedua, hakekat penjelasan dalam sejarah. Ketiga,masalah obyektivitas sejarah (Burston dalam Haryono, 1995:12). 
CIVICS EDUCATION AND SOCIAL SCIENSE JOURNAL(CESSJ)

Volume 2 Nomor 2 Edisi Bulan Desember 2020

\section{Permasalahan Ilmu Sejarah dalam Pembelajaran Sejarah}

Sejarah sebagai mata Pembelajaran yang mempunyai misi atau tujuan pendidikan tertentu dan sejarah sebagai ilmu, (Subakti, 2010) harus dipadukan dalam konsep yang jelas tanpa mengorbankan prinsip-prinsip salah satunya atau keduanya. Hal tersebut penting, agar kekhawatiran tentang subyektifitas sejarah dalam pembelajaran sejarah tidak mengorbankan ilmu sejarah. Sebagaimana pandangan Taufik Abdullah (1996: 8) bahwa sejarah sebagai alat pemupuk ideologi, betapapun luhurnya mempunyai resiko yang bisa meniadakan validitas dari apa yang akan disampaikan. Pemisahan kurikulum antara sejarah "kognitif" (pengetahuan) dengan yang "afektif "(perasaan) yang pernah dilakukan, bukan saja artifisial, tetapi juga memperlihatkan kemandulan dalam pemikiran kesejarahan. Seakan-akan, sejarah yang diketahui tidak bertolak dari keingintahuan yang subyektif, demi didapatkan kearifan yang afektif.

Mengutip pernyataan dari Elton, sering muncul kecurigaan di kalangan sejarawan bahkan para pendidik, terhadap alasan mengkaitkan sejarah dengan proses pendidikan. Proses pendidikan sejarah dianggap hanya menjadi sumber kecenderungan etnosentris bahkan mengarah ke "xenophobia". Sementara itu, Namier berpendapat bahwa peran sejarah sebagai "moral precepts" atau ajaran moral dianggap dapat menjelma menjadi indoktrinasi sebagai legitimasi doktrin atau ideologi tertentu (Elton dalam I Gde Widja, 1997:174).

Selain itu, Mahasin berpandangan bahwa kritik umum kepada pendukung nilai edukatif sejarah dalam penanaman nilai-nilai sejarah melalui proses pendidikan yang lebih menonjol adalah pencapaian tujuan-tujuan edukatif yang bersifat ekstrinsik atau instrumental. Padahal dalam teori belajar yang lebih utama adalah nilai instrinsik. Penekanan sifat ekstrinsik atau instrumental dalam pendidikan sejarah akan lebih mengarah pada pemahaman nilai sejarah sebagai landasan bagi pembentukan semacam alat cetak membentuk manusia yang sudah ditentukan sebelumnya (predefined person) baik dalam rangka " cultural transmission" maupun dalam penyiapan " moral precepts" bagi generasi baru. Dalam kerangka berpikir seperti ini, muncul kecenderungan atau dorongan pemujaan berlebihan terhadap masa lampau yang pada gilirannya memberi peluang bagi kekaburan realitas sejarah demi kepentingan masa kini atau kecenderungan presentisme. Pengaburan seperti ini bisa mendorong generasi baru hanya terpesona atau mengagumi masa lampau tanpa pernah berpikir secara kreatif merencanakan bangunan masa depannya ( Mahasin dalam I Gde Widja, 1997:176). Menurut Taufik Abdullah (1996: 11) jika disimpulkan, sejarah sebagai wacana intelektual akan tampil secara bertahap dengan berbagai wajah. Pertama, sebagai sejarah yang bernada moralistik, yang merupakan pertanggungjawaban rasional akan keharusan hidup bermasyarakat. Kedua, sejarah sebagai alat pengetahuan praktis, yaitu sebagai kaca pembanding untuk mengetahui struktur hari dan dunia kini dan ketiga, sejarah sebagai pembimbing kearah pemahaman, yaitu sebagai alat dan penolong untuk memungkinkan terjadinya dialog yang 
kreatif dengan pergolakan jaman yang melintas dalam pengalaman hidupnya atau alat untuk memahami dunia intellegently.

Sebagai jalan tengah memahami permasalahan di atas, perlu ditekankam strategi dasar berupa penanaman nilai yang dinamis progresif. Dalam perspektif ini, apabila dalam proses belajar-mengajar sejarah tidak bisa dihindarkan mengajak siswa untuk mengambil nilai-nilai dari masa lampau, bukanlah dimaksudkan agar siswa terpaku dan terpesona pada kegemilangan masa lampau. Nilai-nilai masa lampau diperlukan untuk menjadi kekuatan motivasi menghadapi tantangan masa depan (I Gde Widja, 1997: 183).

Sejarah sebagai ilmu mengandung syarat-syarat ilmiah yang harus dipenuhi sebagai disiplin ilmu tertentu. Persepsi tentang sejarah harus jelas bagi guru yang mengajarkan sejarah sebagai mata Pembelajaran. Tujuan sejarah berbeda dengan tujuan Pembelajaran sejarah. Tujuan sejarah dapat bersifat filosofis, tetapi Pembelajaran sejarah mempunyai tujuan tertentu dalam rangka pendidikan atau bersifat didaktis. Harus disadari bahwa mata Pembelajaran-mata Pembelajaran tidak harus bersifat ilmu murni, apalagi untuk pendidikan tingkat dasar dan menengah. Mata Pembelajaran sebagai alat mengabdi kepada tujuan pendidikan yang multi-aspek. Meskipun demikian, sejarah sebagai mata Pembelajaran tidak mengabaikan prinsip-prinsip keilmuan, konsep dasar dan prinsip keilmuan (Siswanto dan Sukamto, 1991: 22-23).

\section{Tujuan Pembelajaran Sejarah}

Sebagaimana telah disinggung sebelumnya, bahwa pembelajaran sejarah merupakan perpaduan antara pembelajaran itu sendiri dan ilmu sejarah, yang mana keduanya tetap memperhatikan tujuan pendidikan secara umum. Pemerintah sebagai pemegang otoritas pendidikan berpendapat tentang tujuan dari mata Pembelajaran sejarah melalui Peraturan Menteri Pendidikan Nasional. Menurut Peraturan Menteri Pendidikan Nasional Republik Indonesia Nomor 22 tahun 2006 tentang standar isi tang tercantum dalam lampiran Peraturan Menteri ini, bahwa mata Pembelajaran Sejarah bertujuan agar peserta didik memiliki kemampuan sebagai berikut: (1) Membangun kesadaran peserta didik tentang pentingnya waktu dan tempat yang merupakan sebuah proses dari masa lampau, masa kini, dan masa depan (2) Melatih daya kritis peserta didik untuk memahami fakta sejarah secara benar dengan didasarkan pada pendekatan ilmiah dan metodologi keilmuan (3) Menumbuhkan apresiasi dan penghargaan peserta didik terhadap peninggalan sejarah sebagai bukti peradaban bangsa Indonesia di masa lampau (4) Menumbuhkan pemahaman peserta didik terhadap proses terbentuknya bangsa Indonesia melalui sejarah yang panjang dan masih berproses hingga masa kini dan masa yang akan datan (5) Menumbuhkan kesadaran dalam diri peserta didik sebagai bagian dari bangsa Indonesia yang memiliki rasa bangga dan cinta tanah air yang dapat diimplementasikan dalam berbagai bidang kehidupan baik nasional maupun internasional.

Pembelajaran sejarah penting dalam pembentukan nilai-nilai karakter termasuk membentuk jiwa patriotisme dan rasa kebangsaan.("Implementasi Pendidikan Karakter Dalam Membentuk Sikap Dan Perilaku Sosial Peserta Didik Melalui Pembelajaran Sejarah Di SMA PGRI 1 Pati Tahun Pelajaran 2017/2018," 
2018) Suatu pengetahuan sejarah yang ditunjang pengalaman praktis warga negara yang baik di sekolah membantu memperkuat loyalitas dan membantu anak-anak menemukan dirinya dengan latar belakang sejarah luas (Jarolimek, 1971: 221). Rowse (1963: 111) menegaskan bahwa sejarah adalah suatu mata Pembelajaran yang bernilai pendidikan tinggi. Sementara itu Collingwod (1973: 1520) mengatakan bahwa nilai sejarah adalah mengajarkan kepada kita tentang manusia dan apa yang telah dilakukannya. Dalam konteks pembentukan identitas nasional, pengetahuan sejarah mempunyai fungsi fundamental (Sartono Kartodirdjo, 1993b:247). Menurut Hamid Hasan dalam Kongres Nasional Sejarah tahun 1996, secara tradisional tujuan kurikulum pendidikan sejarah selalu diasosiasikan dengan tiga pandangan yaitu: (1) "perenialisme" yang memandang bahwa pendidikan sejarah haruslah mengembangkan tugas sebagai wahana " transmission of culture". Pembelajaran sejarah hendaklah diajarkan sebagai pengetahuan yang dapat membawa siswa kepada penghargaan yang tinggi terhadap " the glorius past". Kurikulum sejarah diharapkan dapat mengembangkan kemampuan anak didik dan generasi penerus untuk mampu menghargai hasil karya agung bangsa di mada lampau, memupuk rasa bangga sebagai bangsa, rasa cinta tanah air, persatuan dan kesatuan nasional. (2) esensialisme, menurut pandangan ini, kurikulum sejarah haruslah mengembangkan pendidikan sejarah sebagai pendidikan disiplin ilmu dan bukan hanya terbatas pada pendidikan pengetahuan sejarah. Dalam pandangan aliran esensialisme, siswa yang belajar sejarah harus diasah kemampuan intelektualnya sesuai dengan tradisi intelektual sejarah sebagai disiplin ilmu. Kemampuan intelektual keilmuan antara lain menghendaki kemampuan berfikir kritis dan analitis terutama dikaitkan dalam konteks berfikir yang didasarkan filsafat keilmuan. (3) rekonstruksi sosial, pandangan ini menganggap bahwa kurikulum pendidikan sejarah haruslah diarahkan pada kajian yang mengangkut kehidupan masa kini dengan problema masa kini. Pengetahuan sejarah diharapkan dapat membantu siswa mengkaji masalah untuk memecahkan permasalahan. Kecenderungan-kecenderungan yang terjadi dalam sejarah masa lampau sebagai Pembelajaran yang dapat dimanfaatkan bagi kehidupan siswa masa kini (Hamid Hasan , 1997:138-139). Namun klasifikasi seperti pandangan di atas tidak perlu dijadikan pegangan mutlak dan terpisah oleh para pengembang kurikulum sejarah. Sebagai wahana pendidikan, kurikulum sejarah harus diarahkan untuk mencapai berbagai tujuan seperti pengembangan rasa kebangsaan, kebanggan atas prestasi gemilang masa lalu bangsa, mampu menarik Pembelajaran dari peristiwa masa lampau untuk digunakan dalam melanjutkan prestasi gemilang bangsa bagi kehidupan masa sekarang dan yang akan datang (Hamid Hasan , 1997:139).

Hal yang wajar terjadi perbedaan sudut pandang dalam memahami kenyataan sosial termasuk dalam masalah sejarah. Hal ini juga dikemukakan oleh Taufik Abdullah (1996:5) bahwa sejarah sebagai ingatan kolektif memberikan keprihatinan sosial-kultural akan hasrat peneguhan integrasi. Dalam konteks ini, terkaburlah batas-batas antara " kepastian sejarah" dengan "kewajaran sejarah" , antara “ apa yang sesungguhnya telah terjadi' dan " apa yang semestinya harus terjadi”. Ungkapan lain untuk menjelaskan hal tersebut adalah terbaurlah hasil 
rekonstruksi kritis terhadap sumber sejarah dengan keinginan akan masa lalu sebagai landasan kearifan masa kini.

Namun usaha untuk menjadikan sejarah sebagai sumber inspirasi ataupun sebagai landasan nilai merupakan hal yang sah, baik secara akademis maupun secara etis (Taufik Abudullah,1996: 7). Pembelajaran sejarah lebih bersifat " confluent" artinya dapat untuk mengembangkan berbagai ranah sekaligus. Ranah kognisi, afeksi dan konasi secara bersama-sama membentuk "sikap keseluruhan". Aspek kognisi merupakan penggerak perubahan karena informasi yang diterima menentukan perasaan dan kemauan untuk bertindak. Kognisi yang salah akan menimbulkan afeksi dan konasi yang salah pula. Afeksi dan konasi yang benar hanya dapat dihasilkan oleh kognasi yang benar (Mar'at, 1982 : 13). Ini berarti bahwa Pembelajaran sejarah yang salah akan menimbulkan sikap yang salah, palsu atau munafik. Bila salah, maka tindakan lahirnya juga menghasilkan tindakan yang salah ( Moedjanto, 1985: 6).

Berfokus pada fungsi Pembelajaran sejarah untuk meningkatkan proses penyadaran diri, maka dua aspek didaktik sejarah perlu ditonjolkan yaitu (1) segi teknik penyampaian atau metodenya dan (2) segi substansialnya atau silabus. Kedua aspek terdapat pengaruh timbal balik, keduanya bertalian dengan usia serta tingkat pendidikan anak didik. Prinsip pemilihan substansi dalam didaktif sejarah adalah ( Sartono Kartodirdjo, 1993:254-257): (1) pendekatan secara lokosentris, mulai dengan mengenal lokasi sejarah di sekitarnya (2) pendekatan konsentris, mulai lingkungan dekat meluas ke lingkup nasional terus ke yang internasional (3) temasentris yaitu pilihan tema tertentu yang menarik sekitar pahlawan atau monumen, dan lain sebagainya (4) kronologi: urutan kejadian menurut waktu (5) tingkatan presentasi dari deskriptif-naratif ke deskriptif-analitis, mulai dari cerita tentang " bagaimana" terjadinya, sampai pada "mengapa"-nya (6) sejarah garis besar dan menyeluruh.

Inti pembelajaran sejarah adalah bagaimana menanamkan nilai-nilai kepahlawanan, kecintaan terhadap bangsa, jati diri dan budi pekerti kepada anak didik. Buku Pembelajaran sejarah hendaknya disusun dengan ketentuan-ketentuan ilmiah yang berlandaskan pada tujuan pendidikan nasional ( Hugiono \& Poerwantana, 1987:90). Melalui proses belajar sejarah bukan semata-mata menghapal fakta, siswa dapat mengenal kehidupan bangsanya secara lebih baik dan mempersiapkan kehidupan pribadi dan bangsanya yang lebih siap untuk jangka selanjutnya ( Hamid Hasan, 1997:141). Sementara itu, Krug (1967:22) berpendapat bahwa Pembelajaran sejarah bangsa merupakan upaya terbaik untuk memperkuat kesatuan nasional dan untuk menanamkan semangat cinta tanah air dan jiwa patriotik. Sedangkan Sartono Kartodirdjo (1993:258) menyatakan peranan strategis Pembelajaran sejarah dalam rangka pembangunan bangsa menuntut suatu penyelenggaran Pembelajaran sejarah sebagai pemahaman dan penyadaran, sehingga mampu membangkitkan semangat pengabdian yang tinggi, penuh rasa tanggung jawab serta kewajiban. Kepekaannya terhadap sejarah akan melahirkan aspirasi dan inspirasi untuk melaksanakan tugasnya sebagai warga negara.

Tujuan mempelajari sejarah tidaklah sama dengan tujuan sejarah, menyangkut persoalan didaktis dan juga filsafat. Tujuan Pembelajaran sejarah 
merupakan bagian dari tujuan pendidikan. Sejarah sebagai bahan Pembelajaran harus disusun searah dengan dasar dan tujuan Pendidikan Nasional (Hugiono \& Poerwantana,1987:88). Anak didik harus mampu menemukan nilai-nilai yang ada pada materi sejarah yang dipelajarinya dan mampu merekonstruksi hubungan antar nilai-nilai yang terkandung dalam materi Pembelajaran sejarah tersebut, baik dalam konteks hubungan antar nilai-nilai yang terdapat dalam materi sejarah yang disampaikan secara parsial maupun hubungannya dengan nilai-nilai yang terjadi saat ini. Sebab pengalaman-pengalaman dalam sejarah bukan hanya untuk diketahui, tetapi diharapkan dapat dipakai untuk memperbaiki usaha-usaha di masa mendatang (Imam Barnadib: 1973:45).

Sejarahlah yang menjadi sumber inspirasi dan aspirasi generasi muda dengan pengungkapan model-model tokoh sejarah dan pelbagai bidang. Maka dari itu, sejarah masih relevan untuk dipakai menjadi perbendaharaan suri-tauladan, berkorban untuk tanah air, berdedikasi tinggi dalam pengabdian, tanggung jawab sosial besar, kewajiban serta keterlibatan penuh dalam hal-ihwal bangsa dan tanah air. Sartono Kartodirdjo (Sartono Kartodirdjo, 1993:247) berpendapat bahwa pembelajaran sejarah berkedudukan sangat strategis dalam pendidikan nasional sebagai "soko guru" dalam pembangunan bangsa. Pembelajaran sejarah perlu disempurnakan agar dapat berfungsi secara lebih efektif, yaitu penyadaran warga negara dalam melaksanakan tugas kewajibannya dalam rangka pembangunan nasional.

Tujuan Pembelajaran Sejarah Nasional ialah (a) membangkitkan, mengembangkan, serta memelihara semangat kebangsaan; (b) membangkitkan hasrat mewujudkan cita-cita kebangsaan dalam segala lapangan; (c) membangkitkan hasrat mempelajari sejarah kebangsaan dan mempelajarinya sebagai bagian dari sejarah dunia; (d) menyadarkan anak tentang cita-cita nasional untuk mewujudkan cita-cita itu sepanjang masa ( Moh. Ali, 2005:178). Menurut Wahid Siswoyo dalam bukunya "Seminar Sejarah" yang dikutip oleh Hugiono \& Poerwantana (1987:7), dikemukakan beberapa hal, antara lain: (1) Sejarah dapat menumbuhkan rasa nasionalisme. (2) Sejarah yang mempunyai fungsi pedagogis serta merupakan alat bagi pendidikan membutuhkan pedoman atau pegangan yang dapat digunakan untuk mencapai cita- cita Pendidikan Nasional. Melalui pendidikan sejarah yakni dalam bentuk kegiatan belajar mengajar, proses sosialisasi sikap nasionalisme dapat dilaksanakan secara lebih sistematik dan terencana, yaitu melalui proses internalisasi. Proses internalisasi merupakan proses untuk menjadikan suatu sikap sebagai bagian dari kepribadian seseorang. Dalam upaya mensosialisasikan sikap nasionalisme, strategi belajar mengajar pendidikan sejarah dilakukan melalui tahap pengenalan dan pemahaman, tahap penerimaan, dan tahap pengintegrasian (Ibnu Hizam: 2007:289).

\section{Pendidikan karakter}

Terminologi pendidikan karakter mulai dikenalkan sejak tahun 1900-an. Thomas Lickona dianggap sebagai pengusungnya, terutama ketika ia menulis buku The Return of Character Education kemudian disusul bukunya Educating for Character: How Our School can Teach Respect and Responsibility. Melalui buku 
tersebut ia menyadarkan dunia barat terhadap pentingnya pendidikan karakter. Muslich (2011) mengatakan bahwa pendidikan karakter merupakan suatu sistem penanaman nilai-nilai karakter kepada warga sekolah yang meliputi komponen pengetahuan, kesadaran atau kemauan, dan tindakan untuk melaksanakan nilainilai tersebut baik terhadap Tuhan Yang Maha Esa, diri sendiri, sesama, lingkungan, maupun kebangsaan sehingga menjadi manusia insan kamil. Gaffar (dalam Kesuma dkk, 2012) mendefinisikan pendidikan karakter sebagai sebuah proses transformasi nilai-nilai kehidupan untuk ditumbuhkembangkan dalam kepribadian seseorang sehingga menjadi satu dalam perilaku kehidupan orang itu. Terdapat tiga ide pikiran penting dalam definisi tersebut, yaitu pertama proses transformasi nilai-nilai, kedua ditumbuhkembangkan dalam kepribadian, dan ketiga menjadi satu dalam perilaku. Pendidikan karakter menurut Hamid dan Saebani (2013) adalah pendidikan budi pekerti yang menyentuh ranah kognitif, afektif, dan psikomotorik. Pendidikan karakter menjamah unsur mendalam dari pengetahuan, perasaan, dan tindakan. Pendidikan karakter menyatukan tiga unsur tersebut. Secara akademik, pendidikan karakter dimaknai sebagai pendidikan nilai, pendidikan budi pekerti, pendidikan moral, pendidikan watak, yang tujuannya mengembangkan kemampuan siswa untuk memberikan keputusan baikburuk, memelihara yang baik dan mewujudkan kebaikan dalam kehidupan seharihari.

Samani dan Hariyanto (2014) juga mengatakan bahwa pendidikan karakter adalah proses pemberian tuntutan kepada peserta didik untuk menjadi manusia seutuhnya yang berkarakter dalam dimensi hati, pikir, raga, serta rasa dan karsa. Pendidikan karakter dapat dimaknai sebagai pendidikan nilai, pendidikan budi pekerti, pendidikan moral, pendidikan watak, yang bertujuan mengembangkan kemampuan peserta didik untuk memberikan keputusan baikburuk, memelihara apa yang baik, dan mewujudkan kebaikan itu dalam kehidupan sehari-hari dengan sepenuh hati. Pendidikan karakter menurut Abidin (2012) dimaknai sebagai pendidikan yang mengembangkan nilai-nilai karakter pada diri peserta didik sehingga mereka memiliki nilai dan karakter sebagai karakter dirinya, menerapkan nilai-nilai tersebut dalam kehidupan dirinya, sebagai anggota masyarakat, dan warganegara yang religius, nasionalis, produktif dan kreatif. (Euis Sofi, 2016) Menurut Kaimuddin (2014) pendidikan karakter merupakan usaha sadar yang terencana dan terarah melalui lingkungan pembelajaran untuk tumbuh kembangnya seluruh potensi manusia yang memiliki watak berkepribadian baik, bermoral-berakhlak, dan berefek positif konstruktif pada alam dan masyarakat. Lickona (dalam Samani, 2014) mendefinisikan pendidikan karakter sebagai upaya yang sungguh-sungguh untuk membantu seseorang memahami, peduli, dan bertindak dengan landasan inti nilai-nilai etis. Pendidikan karakter sebagai upaya yang dirancang secara sengaja untuk memperbaiki karakter para siswa. Subiantoro (2015) menambahkan pendidikan karakter adalah proses mendidik nilai, budi pekerti, moral dan akhlak yang baik kepada seorang individu agar individu tersebut dapat menjadi manusia seutuhnya yang berkarakter mulia. Pendidikan karakter adalah pendidikan yang memungkinkan seseorang dapat bertindak sesuai norma-norma yang baik. Rangkuman kali ini universitaspsikologi.com akan mengupas seputar pendidikan karakter yang ada, 
mulai dari pengenalan pendidikan karakter secara umum, hingga seluk beluk isi yang ada dalam pendidikan karakter tersebut, mari kita simak. Pengertian Pendidikan Karakter dan Aspeknya Menurut Para Ahli - Universitas Psikologi | Warning - Copyright!

Sumber Tulisan: https://www.universitaspsikologi.com/2019/11/ pengertianpendidikan-karakter-dan-aspek-karakter-menurut-ahli.html

Berdasarkan pendapat di atas, dapat disimpulkan pendidikan karakter adalah sistem pendidikan yang mendorong anak didik menanamkan nilai-nilai karakter melibatkan aspek pengetahuan, perasaan, tindakan, kesadaran atau kemauan, merupakan upaya yang dirancang dan dilaksanakan secara sistematis untuk membantu peserta didik dalam memahami nilai-nilai perilaku yang berhubungan dengan ketuhanan, diri sendiri, sesama manusia, lingkungan berdasarkan norma agama, hukum, tata karma, dan adat istiadat.

Aspek-aspek Pendidikan Karakter Hamid dan Saebani (2013) mengatakan bahwa secara akademik, pendidikan karakter dimaknai sebagai pendidikan nilai, pendidikan budi pekerti, pendidikan moral, pendidikan watak, yang tujuannya mengembangkan kemampuan siswa untuk memberikan keputusan baik-buruk, memelihara yang baik dan mewujudkan kebaikan dalam kehidupan sehari-hari. Aspek-aspek pendidikan karakter terdiri dari sembilan pilar yang saling terkait, yaitu: Tanggung jawab (responsibility), artinya menghadapi resiko dari perbuatan yang sudah dilakukan; Rasa hormat (respect), artinya bersikap sopan, etis, dan menghargai orang lain secara proporsional; Keadilan (fairness), artinya meletakkan segala sesuatu sesuai dengan porsinya, hidup tertib dan disiplin, tidak berpihak karena kepentingan yang menguntungkan diri sendiri, dan menaati hukum tanpa pamrih dan penuh kesadaran dan keikhlasan; Keberanian (courage), artinya berani menegakkan kebenaran atas nama kebenaran; Kejujuran (honesty), artinya menjauhkan diri dari sikap penuh dusta; Kewarganegaraan (citizenship), artinya mengerti dan menjalankan kehidupan sosial-kemasyarakatan sebagai warga negara yang baik dan taat hukum; Disiplin diri (self-discipline), artinya menjalani kehidupan dengan teratur dan terencana dan tidak bersikap sembrono, serta berhati-hati; Peduli (caring), artinya berempati kepada nasib orang lain dan jika memiliki kemampuan ikut meringankan bebannya; Ketekunan (perseverance), artinya memerhatikan dan mengambil pelajaran dari sisi positif dari semua pengalaman hidup, meningkatkan pemahaman kognitif terhadap semua pelajaran yang diperoleh dari bangku sekolah dan lingkungan masyarakat.(Marharjono, 2020)

Pembentukan karakter merupakan salah satu tujuan pendidikan nasional. Pasal I UU Sisdiknas tahun 2003 menyatakan bahwa diantara tujuan pendidikan nasional adalah mengembangkan potensi peserta didik untuk memiliki kecerdasan, kepribadian, dan akhlak mulia. Amanah Undang-undang Sisdiknas tahun 2003 bermaksud agar pendidikan tidak hanya membentuk insan Indonesia yang cerdas, tetapi juga berkepribadian atau berkarakter, sehingga nantinya akan lahir generasi bangsa yang tumbuh berkembang dengan karakter yang bernapas nilai luhur bangsa serta agama. Berdasarkan penjelasan tersebut Hamid dan Saebani (2013) mengungkapkan bahwa pendidikan karakter bertujuan : 1) 
membentuk siswa berpikir rasional, dewasa, dan bertanggung jawab; 2) mengembangkan sikap mental yang terpuji; 3) membina kepekaan sosial anak didik; 4) membangun mental optimis dalam menjalani kehidupan dengan penuh tantangan; 5) membentuk kecerdasan emosional; 6) membentuk anak didik yang berwatak pengasih, penyayang, sabar, beriman, takwa, bertanggung jawab, amanah, jujur, adil, dan mandiri.(Rohendi, 2016) Tujuan pendidikan karakter yang berkaitan dengan pembentukan mental dan sikap anak didik dikelola dengan menanmkan nilai-nilai religius dan nilai tradisional yang positif. Nilai itu perlu ditanamkan dengan intensitas yang sama pada semua mata pelajaran. Oleh karena itu, perlu dipilih sejumlah nilai utama sebagai pangkal tolak bagi penanaman nilai-nilai lainnya.(Jalil, 2016) Kesuma dkk (2012) mengungkapkan tujuan pendidikan karakter adalah memfasilitasi penguatan dan pengembangan nilai-nilai tertentu sehingga terwujud dalam perilaku anak, baik ketika proses sekolah maupun setelah proses sekolah (setelah lulus dari sekolah). Ia menguraikan tujuan pendidikan karakter sebagai berikut: Menguatkan dan mengembangkan nilai-nilai kehidupan yang dianggap penting dan perlu sehingga menjadi kepribadian/kepemilikan peserta didik yang khas sebagaimana nilai-nilai yang dikembangkan. Mengoreksi perilaku peserta didik yang tidak bersesuaian dengan nilai-nilai yang dikembangkan oleh sekolah. Membangun koneksi yang harmoni dengan keluarga dan masyarakat dalam memerankan tanggung jawab pendidikan karakter secara bersama.

\section{Pendidikan Karakter dalam Pembelajaran di Sekolah}

Terwujudnya pembinaan karakter di sekolah secara umum, menurut Hamid dan Saebani (2013) perlu diperhatikan hal-hal berikut ini: Sekolah atau lembaga pendidikan adalah sebuah organisasi yang seharusnya selalu mengusahakan dan mengembangkan perilaku organisasinya agar menjadi organisasi yang dapat membentuk perilaku para siswa agar menjadi orang-orang yang sukses, tidak hanya mutu akademiknya, tetapi sekaligus mutu nonakademiknya. Sekolah sebaiknya merumuskan visi, misi, dan tujuan sekolah yang secara tegas menyebutkan keinginan terwujudnya karakter mulia di sekolah. Pengembangan akhlak mulia di sekolah akan berhasil jika ditunjang kesadaran yang tinggi dari seluruh civitas sekolah, orang tua, dan masyarakat untuk mewujudkannya. Mengembangkan karakter mulia di sekolah juga diperlukan program-program sekolah yang secara tegas dan terperinci mendukung terwujudnya karakter akhlak mulia tersebut. Program-program ini dirancang dalam rangka pengembangan atau pembiasaan siswa sehari-hari, baik dalam pengamalan ajaran-ajaran agama maupun nilai-nilai moral dan etika universal dan dituangkan dalam peraturan sekolah. Membangun karakter mulia tidak cukup hanya dengan melalui mata pelajaran tertentu, seperti pendidikan agama dan pendidikan kewarganegaraan, tetapi juga melalui semua mata pelajaran yang diajarkan di sekolah yang ditempuh dengan cara mengintegrasikan pendidikan karakter dalam setiap pembeajaran semua bidang studi (mata pelajaran) di sekolah. Begitu juga, membangun karakter mulia harus menjadi tanggungjawab semua guru, utamanya guru agama, guru PPKN atau guru bimbingan konseling. Terwujudnya karakter mulia di sekolah juga membutuhkan dukungan sarana 
prasarana sekolah yang memadai. Oleh karena itu, sekolah sebaiknya menyediakan fasilitas yang cukup demi kelancaran pengembangan karakter yang mulia ini.

Pembinaan karakter siswa di sekolah meskipun bisa terjadi dengan sendirinya, jika disertai kesadaran yang tinggi dari semua komponen sekolah, lebih efektif jika pengembangan karakter di sekolah ini ditangani oleh tim khusus yang dibentuk sekolah yang bertanggungjawab penuh dalam pembinaan karakter ini. Tim inilah yang merancang program-program pembinaan karakter, kemudian melaksanakannya hingga melakukan evaluasi programnya hingga terlihat hasil yang diharapkan. Sekolah berbasis pendidikan agama, model yang seharusnya dikembangkan untuk pengembangan karakter adalah: (1) pendidikan agama hendaknya menjadi basis utama dalam pengembangan karakter bagi siswa di sekolah. Ajaran dasar agama mulai dari keimanan (akidah), ritual (ibadah dan muamalah), serta moral (akhlak) harus benar-benar ditanamkan dengan baik dan benar kepada siswa agar tidak ada lagi sikap dan perilaku siswa yang meyimpang dari ketentuan agamanya; (2) sebenarnya karakter atau akhlak sebagai hasil dari proses seseorang melaksanakan ajaran agamanya. Karena itu, harusnya karakter akan terbentuk dengan sendirinya, jika seseorang telah menjalankan ajaran agamanya dengan baik. Jadi, pendidikan agaman harus benar-benar diajarkan secara efektif kepada siswa, tidak terbatas pada nilai kognitif, tetapi juga menyentuh sikap dan perilaku agama; (3) hal penting yang perlu diperhatikan dalam rangka pembinaan karakter yang efektif di sekolah adalah visi, misi, dan tujuan sekolah, kebersamaan, ada program-program yang jelas dan terperinci, pelibatan semua mata pelajaran dan semua guru, ada dukungan sarana prasarana, dan perlu tim khusus.(N, 2005)

Beberapa Kesalahan yang Harus Dihindari dalam Pendidikan Karakter Menurut Sani dan Kadri (2016) terdapat kesalahan yang sering dilakukan oleh pendidik baik orang tua maupun guru dalam mendidik anak. Beberapa hal tersebut yang harus dihindari adalah sebagai berikut: Ucapan pendidik tidak sesuai dengan perbuatan Perbedaan pendapat kedua orang tua dalam mendidik anak Membiarkan anak menjadi korban media Menyerahkan tanggung jawab pendidikan anak kepada pembantu Menampakkan kelemahan dalam mendidik anak Berlebihan dalam memberi hukuman Berusaha mengekang anak secara berlebihan Mendidik anak tidak percaya diri dan merendahkan pribadinya

\section{METODE}

Penelitian ini termasuk jenis penelitian kwalitatif, dengan subjek penelitiannya yaitu Guru bidang studi sejarah, dan siswa kelas X di SMA Veteran 1 Sukoharjo tahun Pembelajaran 2020-2021, dan objek penelitiannya adalah pembelajaran sejarah secara daring dan pendidikan karakter.

Metode pengumpulan data menggunakan wawancara dengan aplikasi google form dan WA serta dokumentasi. Validitas data dilakukan dengan trianggulasi sumber dan metode. Teknik analisis data dilakukan dengan tehnik kualitatif yang mencukup 3 hal yaitu: reeduksi data, display data dan verifikasi data.(Moleong, 2017)(Sugiyono, 2016) 


\section{HASIL PENELITIAN DAN PEMBAHASAN}

\section{Hasil Penelitian}

Data hasil wawancara dengan Guru Bidang studi sejarah kelas $\mathrm{X} 1, \mathrm{X} 2$, dan X3 di SMA Veteran 1 Sukoharjo tentang problematika pembelajaran sejarah daring dan solusinya dalam perspektif pendidikan karakter diperoleh informasi sebagai berikut: Terkait problematika pemeblajaran sejarah daring, permasalahan yang dihadapi adalah: koneksi internet tidak stabil, aplikasi sering error, pemahaman IT minim, pengembangan bahan ajar cukup sulit, merubah para paradigm dari pembelajaran tekstual menjadi kontekstual cukup sulit, keterbatasan dalam pengembangan metode dan media pembelajaran, sulitnya membuat soal yang mengukur aspek sikap dan keterampilan, dukungan HP yang kurang . Selanjutnya data hasil wawancara dengan siswa kelas X di di SMA Veteran 1 Sukoharjo diperoleh informasi sebagai berikut: kurang memahami IT dan aplikasi, koneksi internet kurang lancer, jenuh dengan pembelajaran daring, mata pedas, HP kurang mendukung, waktu sangat terbatas, guru cara mengajarnya kurang menarik, metode dan media yang digunakan kurang variatif. Data hasil wawancara dengan orang tua /wali murid siswa kelas X di SMA Veteran 1 Sukoharjo diperoleh informasi: pemahaman IT dan aplikasi sangat terbatas, mengeluarkan uang untuk membeli pulsa, koneksi internet tidak lancer, waktunya yang sangat terbatas, terjadinya error/gangguan baik video maupun audio, kurang mampu mendapingi karena materinya sulit dan tidak menguasai.

Solusi yang dilakukan oleh guru dalam mengatasi problematika pembelajaran sejarah daring yaitu: dukungan HP harus maksimal, mencari jaringan/sinyal yang kuat, mengembangkan bahan ajar dengan menggunakan peristiwa-peristiwa kontekstual yang terjadi, mengembangkan penggunaan metode dan media yang lebih variatif, merubah gaya mengajar yang lebih variatif, menshare modul melalui WA group sebelum proses pemeblajaran berlangsung. Solusi yang dilakukan oleh siswa kelas $\mathrm{X}$ dalam mengatasi problematika pembelajaran daring adalah: mencari jaringan/koneksi yang kuat, meminjam HP yang memiliki aplikasi yang mendukung daring, setelah selesai mengikuti pemeblajaran dilanjuykan dengan diskusi dengan temantemannya, bertanya pada guru saat mengikuti pembelajaran sejarah daring melalui via WA group. Dan solusi yang dilakukan orang tua dalam mendampingi pembelajaran sejarah daring yaitu: menganggarkan pembelian pulsa, dengan ramah dan setia mendampingi pembelajaran sejarah daring, membantu anaknya jika ada masalah dalam mengikuti pembelajaran jarring.

Pembelajaran daring, solusi dalam perspektif pendidikan karakter. Berdasdarkan wawancara dengan guru bidang studi sejarah melalui daring dan solusi yang dilakukan dalam perspektif pendidikan karakter diperoleh informasi sebagai berikut: nilai-nilai pendidikan karakter yang dapat dijangkau secara maksimal dalam pembelajaran sejarah daring adalah; nilai religius yaitu pada saat seblum dan sesudah pembelajaran sejarah selalu dengan berdoa, nilai tanggung jawab yaitu siswa mengikuti dan mengerjakan 
tugas guru dengan semangat, nilai kedisiplinan yaitu siswa mengerjakan tugas guru serta mengumpulkannya tepat waktu, nilai kejujuran yaitu siswa mengerjakan tugas dikerjakan sendiri, nilai kepeduliaan yaitu siswa membantu temannya untuk mengikuti daring bersama karena HP temannya kurang mendukung untuk daring, sedangkan nilai-nilai karakter yang lainnya kurang maksimal.

\section{Pembahasan}

Peran pendidikan sejarah dalam pembentukan sikap nasionalisme guna mengantisipasi tantangan global dan berbagai gejolak disintegrasi yang melanda Indonesia akhir-akhir ini sangat dibutuhkan, hal ini mengingat pengalaman sejarah membuktikan sikap nasionalisme mampu membangkitkan dinamika sosial di masa lalu. Sikap nasionalisme yang dimiliki rakyat Indonesia telah mampu menghantarkan bangsa menuju kemerdekaan di tengah keterbelakangan pengetahuan rakyat Indonesia dan kuatnya persenjataan penjajah, dalam kontek saat itu. Namun saat ini peran pendidikan sejarah patut dipertanyakan, sikap nasionalisme yang dimiliki bangsa menunjukkan kerapuhan. Konflik antar suku dan agama karena perbedaan nilai, dan upaya beberapa daerah yang ingin memisahkan diri dari Negara Kesatuan Republik Indonesia merupakan bukti bahwa kesatuan nasional masih rapuh (Ibnu Hizam:2007:288).

Dalam Peraturan Menteri Pendidikan Nasional Republik Indonesia Nomor 22 tahun 2006 tentang Standar Isi yang tercantum dalam lampiran Peraturan Menteri, untuk satuan pendidikan dasar dan menengah dijelaskan terkait materi dan tujuan dari pembelajaran sejarah maka mata Pembelajaran Sejarah memiliki arti strategis dalam pembentukan watak dan peradaban bangsa yang bermartabat serta dalam pembentukan manusia Indonesia yang memiliki rasa kebangsaan dan cinta tanah air. Secara umum materi sejarah: (1) mengandung nilai-nilai kepahlawanan, keteladanan, kepeloporan, patriotisme, nasionalisme, dan semangat pantang menyerah yang mendasari proses pembentukan watak dan kepribadian peserta didik; (2) memuat khasanah mengenai peradaban bangsa-bangsa, termasuk peradaban bangsa Indonesia. Materi tersebut merupakan bahan pendidikan yang mendasar bagi proses pembentukan dan penciptaan peradaban bangsa Indonesia di masa depan; (3) menanamkan kesadaran persatuan dan persaudaraan serta solidaritas untuk menjadi perekat bangsa dalam menghadapi ancaman disintegrasi bangsa; (4) sarat dengan ajaran moral dan kearifan yang berguna dalam mengatasi krisis multidimensi yang dihadapi dalam kehidupan seharihari; (5) berguna untuk menanamkan dan mengembangkan sikap bertanggung jawab dalam memelihara keseimbangan dan kelestarian lingkungan hidup(Rossafri \& Shabariah, 2011)

Atas dasar hal tersebut, maka sejarah diberikan kepada seluruh siswa di sekolah dari tingkat dasar (SD dan sederajat) sampai tingkat menengah (SMA dan sederajat) dalam bentuk mata Pembelajaran. Kedudukannya yang penting dan strategis dalam pembangunan watak bangsa merupakan fungsi yang tidak bisa digantikan oleh mata Pembelajaran lainnya. Meskipun 
demikian, terkait dengan materi sejarah dri tingkat dasar sampai menengah, Taufik Abdullah berpendapat agar siswa tidak bosan menerima materi sejarah, maka jika secara faktual yang disampaikan sama namun dalam setiap jenjang pendidikan, peristiwa tersebut akan tampil pada tingkat pengetahuan, pemahaman, serta pemberian keterangan sejarah yang semakin tinggi dan kompleks. Dengan demikian, setiap tingkatan atau tahap diharapkan bisa memberikan kesegaran dan kematangan intelektual (Taufik Abdullah, 1996: 10).

Dari pandangan di atas, dapat disimpulkan bahwa pembelajaran sejarah tidak mengkhususkan mempelajari fakta-fakta dalam sejarah sebagai ilmu namun perpaduan antara sejarah dan tujuan pendidikan pada umumnya. Meski demikian, pembelajaran sejarah berusaha menampilkan fakta sejarah secara obyektif meskipun tetap dalam kerangka fakta sejarah yang sesuai dengan tujuan pendidikan itu sendiri.

Dalam konteks problematika pemeblajaran sejarah dan solusinya bagi siswa kelas $\mathrm{X}$ di SMA Veteran 1 Sukoharjo dalam perspektif pendidikan karakter. Problematika yang dihadapi baik oleh guru bidang studi sejarah, oleh siswa kelas X di SMA Veteran 1 Sukoharjo, maupun oleh orang tua siswa adalah sangat kompleks. Probelmatika yang dihadapia da eprmasamaan dan perbedaan, persamaannya yaitu: koneksi internet tidak maksimal, HP yang kurang mendukung, durasi waktu yang terbatas serta pemahaman It dan aplikasi kurang maksimal.

Dalam hal solusi yang dilakukan oleh guru bidang studi sejarah, oleh siswa kelas X di SMA Veteran 1 Sukoharjo, maupun oleh orang tua siswa juga sangat variatif artinya ada persamaan dan ada perbedaannya. Persamaannya adalah: mencari jaringan koneksi yang maksimal, HP diuapayakan yang mendukung daring, durasi waktu di tambah, pemebrian tugas tidak terlalu banyak, metode dan emdia yang variatif.

Dalam hal pendidikan karakter nilai-nilai karakter yang terakomodir secara maksimal dalam pembelajaran sejarah daring bagi guru bidang studi sejarah, siswa kelas X di SMA Veteran 1 Sukoharjo, maupun oleh orang tua siswa adalah nilai karakter: religius, tanggung jawab, kemandirian, kejujuran dan kepedulian.

\section{SIMPULAN}

Berdasarkan deskripsi data hasil wawancara dengan Hasil wawancara dengan guru bidang studi sejarah, dengan siswa kelas X di SMP Veteran 1 Sukoharjo dan dengan orang tua siswa kelas X di SMP Veteran 1 Sukoharjo serta hasil pembahasan dapat disimpulkan bahwa problematika yang dihadapi dalam pelaksanaan pembelajaran sejarh daring di masa pandemic covid 19 bagi siswa kelas X di SMP Veteran 1 Sukoharjo tahun Pembelajaran 2020-2021 sangat kompleks . Kaitannya solusi yang dilakukan adalah memperbaiki mutu sarana prasarana pembelajaran, koneksi internet serta dukungan dari orang tua. Dalam konteks pendidikan karakter tidak semua nilai karakter yang menurut 
CIVICS EDUCATION AND SOCIAL SCIENSE JOURNAL(CESSJ)

Volume 2 Nomor 2 Edisi Bulan Desember 2020

kemendiknas ada 18 nilai karakter tidak dapat diwujudkan semuanya, sedangkan nilai-nilai karakter yang terjangkau dengan pembelajaran sejarh daring di masa pandemic covid 19 bagi siswa kelas X di SMP Veteran 1 Sukoharjo tahun Pembelajaran 2020-2021 yaitu nilai karakter: disiplin tanggung jawab, dan nilai karakter kemandirian serta nilai karakter religius.

\section{REFERENSI}

Abidin, Yunus. 2012. Model Penilaian Otentik dalam Pembelajaran Membaca Pemahaman Beroreintasi Pendidikan Karakter. Jurnal. Bandung : Universitas Pendidikan Indonesia

Ahmad Johari, S. (2008). Teori Pembelajaran. Psikologi Pendidikan.

Baxter, R., Hastings, N., Law, A., \& Glass, E. J. . (2008). Pengertian Proses Pembelajaran Pembelajaran. Animal Genetics.

Dewi, W. A. F. (2020). Dampak COVID-19 terhadap Implementasi Pembelajaran Daring di Sekolah Dasar. EDUKATIF : JURNAL ILMU PENDIDIKAN. https://doi.org/10.31004/edukatif.v2i1.89

Euis Sofi. (2016). Pembelajaran Berbasis e-learning Pada Mata Pelajaran Sejarah Kebudayaan Islam Kelas viii Madrasah Tsanawiyah Negeri. Jurnal Penelitian Manajemen Pendidikan.

Hamid Hasan, S. 1997. "Kurikulum dan Buku Teks Sejarah" dalam Kongres Nasional Sejarah 1996 Jakarta Sub Tema Perkembangan Teori dan Metodologi dan Orientasi Pendidikan Sejarah. Jakarta : Proyek Inventarisasi dan Dokumentasi Sejarah Nasional Direktorat Jenderal Kebudayaan Departemen Pendidikan dan Kebudayaan

. 2007. 'Kurikulum Pendidikan Sejarah Berbasis Kompetensi'. Makalah pada Seminar Nasional Ikatan Himpunan Mahasiswa Sejarah SeIndonesia (Ikahimsi) XII. Semarang, 16 April 2007.

Hariyono. 1995. Mempelajari Sejarah Secara Efektif. Jakarta : Pustaka Jaya

Hugiono \& Poerwantana,P.K. 1987: Pengantar Ilmu Sejarah. Jakarta : PT Bina Aksara

Hamid, Hamdani \& Saebani, B. Ahmad. 2013. Pendidikan Karakter Perspektif Islam. Bandung : Pustaka Setia

Hernawan, A. H. (2018). Strategi Pembelajaran di SD. Pdgk4105/Modul 1. 
CIVICS EDUCATION AND SOCIAL SCIENSE JOURNAL(CESSJ)

Volume 2 Nomor 2 Edisi Bulan Desember 2020

Implementasi Pendidikan Karakter dalam Membentuk Sikap dan Perilaku Sosial Peserta Didik Melalui Pembelajaran Sejarah di SMA PGRI 1 Pati Tahun Pelajaran 2017/2018. (2018). Indonesian Journal of History Education.

Ibnu Hizam. 2007. "Kontribusi Minat Belajar dan Kemampuan Klarifikasi Nilai Sejarah dalam Pembentukan Sikap Nasionalisme" dalam Jurnal Penelitian Keislaman, Vol. 3, No. 2, Juni 2007.

I Gde Widja. 1989. Pengantar Ilmu Sejarah: Sejarah dalam Perspektif Pendidikan. Semarang: Satya Wacana.

1991. Sejarah Lokal Suatu Perspektif dalam Pembelajaran Sejarah. Bandung: Angkasa.

1997. "Permasalahan Metodologi dalam Pembelajaran Sejarah di Indonesia suatu tinjauan reflektif dalam mengantisipasi perkembangan abad XXI" dalam Kongres Nasional Sejarah 1996 Jakarta Sub Tema Perkembangan Teori dan Metodologi dan Orientasi Pendidikan Sejarah. Jakarta : Proyek Inventarisasi dan Dokumentasi Sejarah Nasional Direktorat Jenderal Kebudayaan Departemen Pendidikan dan Kebudayaan

Jalil, A. (2016). Karakter Pendidikan untuk Membentuk Pendidikan Karakter. Nadwa. https://doi.org/10.21580/nw.2012.6.2.586

Jamaluddin, D., Ratnasih, T., Gunawan, H., \& Paujiah, E. (2020). Pembelajaran Daring Masa Pandemik Covid-19 Pada Calon Guru $\square$ : Hambatan, Solusi dan Proyeksi. Karya Tulis Ilmiah UIN Sunan Gunung Djjati Bandung.

Kaimuddin. 2014. Implementasi Pendidikan Karakter dalam Kurikulum 2013. Jurnal vol 14 no 1

Kartono, Kartini. 2011. Kamus Lengkap Psikologi. Jakarta : Raja Grafindo Persada

Kesuma, dkk. 2012. Pendidikan Karakter kajian teori dan praktik di sekolah. Bandung : Remaja Rosdakarya Offset

Krug, Mark. M. 1967. History and the Social Sciences. Walthan Mass: Braisdell

Muslich, Masnur. 2011. Pendidikan Karakter Menjawab Tantangan Krisis Multidimensional. Jakarta : Bumi Aksara 
CIVICS EDUCATION AND SOCIAL SCIENSE JOURNAL(CESSJ)

Volume 2 Nomor 2 Edisi Bulan Desember 2020

Marharjono, M. (2020). MANFAAT PEMBELAJARAN SEJARAH MENGGUNAKAN GOOGLE CLASSROOM PADA MASA PANDEMI COVID-19. Ideguru: Jurnal Karya Ilmiah Guru. https://doi.org/10.51169/ideguru.v5i1.155

Moleong, L. J. (2017). Metodologi Penelitian Kualitatif (Edisi Revisi). In PT. Remaja Rosda Karya.

Moh. Ali,R. 2005. Pengantar Ilmu Sejarah Indonesia. Yogyakarta: LkiS.

Mursell, James L. 1975. Pembelajaran Berhasil (Edisi terjemahan oleh L.P Simandjuntak dan Soeitoe). Jakarta: Universitas Indonesia Press

N, O. (2005). pentingnya pendidikan karakter dalam dunia pendidikan. Nopan Omeri.

Rohendi, E. (2016). Pendidikan Karakter Di Sekolah. EduHumaniora | Jurnal Pendidikan Dasar Kampus Cibiru. https://doi.org/10.17509/eh.v3i1.2795

Rossafri, M., \& Shabariah, M. S. (2011). Kesan Penggunaan Laman Sosial ke atas Kaedah Perbincangan di dalam Pengajaran dan Pembelajaran Mata Pelajaran Sejarah. Jurnal Teknologi Pendidikan Malaysia.

Sirnayatin, T. A. (2017). Membangun Karakter Bangsa Melalui Pembelajaran Sejarah. SAP (Susunan Artikel Pendidikan). https://doi.org/10.30998/sap.v1i3.1171

Subakti, Y. R. (2010). Paradigma Pembelajaran Sejarah Berbasis Konstruktivisme. Paradigma Pembelajaran Searah.

Sugiyono. (2016). Metode Penelitian Kuantitatif Kualitataif dan Kombinasi (Mixed Methods). Journal of Chemical Information and Modeling.

Syaiful B. Djamarah \& Aswan Zain. 1996. Strategi Belajar Mengajar. Jakarta: Rineka Cipta

Sutrisno Kuntoyo .1985.“ Suatu Catatan Tentang Kesadaran Sejarah”. Dalam Pemikiran Tentang Pembinaan Kesadaran Sejarah Direktorat Sejarah dan Nilai Tradisional Proyek Pembinaan Kesadaran dan Penjernihan Sejarah. Jakarta: Depdikbud

Sidi Gazalba . 1966. Pengantar Sejarah Sebagai Ilmu. Jakarta: Bhatara Karya Aksara. 
CIVICS EDUCATION AND SOCIAL SCIENSE JOURNAL(CESSJ)

Volume 2 Nomor 2 Edisi Bulan Desember 2020

Siswanto dan Sukamto, G.M. 1991. Penafsiran Sejarah. Malang : Pusat Pengembangan Penataran Guru IPS dan PMP.

Sartono Kartodirdjo. 1993.Pendekatan Ilmu Sosial dalam Metodologi Sejarah. Jakarta: PT Gramedia Pustaka Utama

Taufik Abdullah (Ed). 1990. Sejarah Lokal di Indonesia. Yogyakarta : Gadjah Mada University Press.

. 1996. "Di Sekitar Pembelajaran Sejarah yang Refkletif dan Inspiratif”. Dalam Jurnal Sejarah Pemikiran, Rekonstruksi, Persepsi 6 oleh Masyarakat Sejarawan Indonesia. Jakarta: PT Gramedia Pustaka Utama 